\title{
Histomorphometric analysis of the effects of calcitonin on alveolar socket repair in diabetic rats
}

\section{Avaliação histomorfométrica dos efeitos da calcitonina no reparo alveolar em ratos diabéticos}

\author{
Adriana da Mota DELGADO \\ PhD Student - Oral Biopathology Graduate Program - School of Dentistry of São José dos Campos - \\ UNESP - Univ Estadual Paulista - São José dos Campos - SP - Brazil.

\section{Mônica Fernandes GOMES José Benedito de Oliveira AMORIM} \\ Associate Professors - Department of Biosciences and Oral Diagnosis - School of Dentistry of São \\ José dos Campos - UNESP - Univ Estadual Paulista - São José dos Campos - SP - Brazil.
}

\section{Marta Verônica MARIUBA}

Dentist - Private Practice

\begin{abstract}
In order to make a histomorphometric evaluation of the dental alveolus wound healing in chronic presence of salmoncalcitonin $(16 \mathrm{UI} / \mathrm{Kg})$ in the diabetic condition, sixty albino rats were utilized. These animals were divided into three groups: control(C), diabetic (D) and calcitonin-treated diabetic (Dca). The D and Dca groups were given a single $45 \mathrm{mg} /$ $\mathrm{Kg}$ intraperitonial injection of streptozotocin-STZ. After two weeks, all animals were submitted a tooth extraction of the upper right incisor and five animals from each group were sacrificed at 15, 30 e 45 post-operative days. The pieces were fixed, descalcified and embedded in paraffin. The blocks thus obtained were cut at 6 micrometers thick and sections were stained with hematoxylin and eosin for morphological study. According to the results obtained it was verified that the calcitonin-treated animals altered of wound healing after dental extraction, attenuating the impairment of the bone repair dynamic commonly observed in the diabetic status.
\end{abstract}

\section{KEYWORDS:}

Bone repair, diabetes mellitus, salmon calcitonin, socket dental, and streptozotocin.

\section{INTRODUCTION}

Diabetes mellitus, a complex metabolic disorder, is a syndrome characterized by abnormalities in carbohydrate, lipid, and protein metabolism that results either from a profound or an absolute deficiency of insulin or from target tissue resistance to its cellular metabolic effects [1,2]. Vitamin D metabolism, bone and osteoid formation and mineral homeostasis have shown to be altered in experimental diabetes [3-6].

Diabetes specific complications have been related to glucose metabolites termed Advanced Glycation End-products (AGEs). AGEs causes qualitative and quantitative changes in extra cellular matrix components such as collagen and proteoglycans.
These changes produce specific alterations in bone formation and remodeling [5,7-8].

Although oral complications have been described in dental management of uncontrolled diabetes mellitus with xerostomia, infection, poor healing, increased incidence and severity of caries, candidiasis, gingivitis, periodontal disease, periapical abscesses, and burning mouth syndrome [1,9], there are little data correlating this condition with healing of tooth extraction particularly in association of hormone therapy. Salmon calcitonin (sCT) is a therapeutic agent approved by the Food and Drug Administration for the treatment of established osteoporosis [10]. This observation led us to hypothesize that calcitonin could be usefull for the treatment of the individuals 
with diabetic-related osteopenia, particularly in surgical interventions, since the osteopenia is one of the most significant complications of diabetes [11].

Therefore, the present investigation was performed to evaluate the effect of chronic salmon calcitonin treatment on alveolar bone repair, after tooth extraction, in rat during short-term STZ (streptozotocin) -induced diabetes. Bone histology and growth were examined in the upper maxillary of rats using a well-establish model of quantitative bone histomorphometry

\section{Material and Methods}

Sixty animals, (Rattus norvergicus, albinus) Wistar male rats, with body weight of $250 \mathrm{~g}$, were divided into 3 groups: control rats (C) diabetic rats (D) and calcitonin-treated diabetic rats (DCa). These animals were observed in groups of five during one month and kept in cages and fed ad libitum. All animals received human care, according to the National Research Council's criteria and the study protocol was approved by São José dos Campos Dental School Animal Use Committee prior to be started.

Diabetes was induced in animals by an intraperitoneal injection of the pancreatic $\beta$-cell toxin streptozotocin-STZ (Sigma Chemical Co, St. Louis, Mo), freshly dissolved in citrate buffer $\mathrm{pH} 4.5$ at $45 \mathrm{mg} / \mathrm{kg}$ body weight ratio. Using an Advantage II glucometer (Roche Produtos Químicos e Farmacêuticos S.A., São Paulo, Brazil), blood glucose level was monitored $36 \mathrm{~h}$ post STZ-treatment and throughout the duration of the study to determine the hyperglycemic state of the animals. A majority of the animals developed clinical evidence of diabetes within two-weeks following STZ-injection. Animals that failed to develop average blood glucose concentration $(<270 \mathrm{mg} / \mathrm{dl})$ were excluded [12]. During surgical procedures, the animals were anesthetized with an intramuscular injection with acepromazina (preanesthesic, Acepran 1\%®, Univet S.A. Indústria Veterinária, São Paulo, Brazil) and ketamina Dopalen (anesthesic, Agribands Saúde Animal, São Paulo, Brazil). Two drugs were associated at 1:1 proportion and administrated at $0.1 \mathrm{ml} / 100 \mathrm{~g}$ dose. The upper right incisors were extracted with forceps after disconnection of the surrounding gingiva and luxation with an enamel hatchet presenting a cutting edge. The animals were sacrificed by anesthetic over dose at 15 , 30, 45 days postoperatively. The rats' maxillae were removed in bloc, fixed in $10 \%$ neutral formalin for 48 h. After fixation, the maxilla was dissected and divided along the median sagittal plane. The right halves were cut tangentially to the distal surface of the molars, decalcified by Plank-Rychlo solution, and processed for paraffin embedding. Longitudinal, semiserial 6 - $\mu \mathrm{m}$-thick sections, cut at intervals of 70 $\mu \mathrm{m}$, were stained with hematoxylin and eosin.n

The Dca groups received alternately calcitonin (MIACALCIC- salmon calcitonin - Sandoz ${ }^{\circledR}$ farmacêutica) freshly dissolved in saline solution at a $16 \mathrm{UI} / \mathrm{kg}$ bodyweight ratio, by subcutaneous injection before tooth extraction [13].

The histomorphometric analysis was accomplished by the experimental principle of the stereology that consists in observing the three dimensions quantitative parameters of the anatomic structures in the histologic sections, using the geometry and statistic analysis. The aim of the application this method is to study a sampling by arbitrary and isotropic histologic sections. A II Zeiss reticule adapted to a compensation ocular KPL 8X Zeiss microscope (Zeiss, Thornwood, NY, USA) to evaluate the bone density (BD). The reticule image was superimposed on the desired histological fields. The reticule points $(\mathrm{Ni})$ and the total number of points over the alveolar socket $(\mathrm{N})$ were counted. The bone density was evaluated with the following formula: $\mathrm{BD}=$ number of points in bone trabeculae $(\mathrm{Ni}) /$ total number of points in the alveolar socket $(\mathrm{N})$. The chosen alveolar socket was submitted for examination with serial microscopy sections, from which approximately 100 sections were obtained. From these sections, five were randomly chosen for morphometric analysis. Subsequently, six histological fields from each section at the surgical bone defect region were analyzed. At this step, an objective 40X and an ocular KPL 8X of an optical microscope, (Olympus CH-2, Olympus, Tokyo, Japan) were used. The objective showed a 100-point reticule corresponding to $7,840 \mu \mathrm{m} 2$ for measuring the bone tissue area [14].

Data are expressed as means \pm SE. Differences between the experimental groups were determined by performing a one-way analysis of variance (ANOVA) followed by Tukey-Kramer method. A p value lower than 0.05 was considered for significant differences.

\section{RESULTS}

The diabetic state in all animals (blood glucose $>270 \mathrm{mg} / \mathrm{dL}$ ) was predictably induced and maintained throughout the healing period. The diabetic state was followed by changes on clinical aspects (loss body mass, ployuria, polydipsia, polyphagia), with some animals also presenting retinophaty. The mean values of 
plasma glucose in the diabetic rats showed statistically significant when compared with control group, signalizing the efficacy of the STZ-induction (Table 1). During the experiment, a discrete increase of the glucose level in the DCa groups was observed. This fact might be related to the diabetogenic effect of the salmon calcitonin, as described by others studies [15-18].

The control rats presented increase in the body mass during all the observation periods. As expected, the control rats weight increased by approximately $75 \%$ after one-month. The diabetic groups continued to gain weight but at a reduced rate during the STZinduced phase of the study.

\section{Table 1- Means of the plasma glucose and BODY WEIGHT OF THE STUDIES GROUPS}

\begin{tabular}{c|c|c}
\hline Groups & Plasm glucose $(\mathrm{mg} / \mathrm{dl})$ & Body weight $(\mathrm{g})$ \\
\hline Control & $109.8 \pm 5.54$ & $432.71 \pm 11.20$ \\
\hline Diabetic rats & $375.8 \pm 45.21^{*}$ & $331.42 \pm 9.42$ \\
\hline $\begin{array}{c}\text { Diabetic rats treated } \\
\text { with calciton }\end{array}$ & $419.6 \pm 20.73^{*}$ & $317.28 \pm 9.83$ \\
\hline
\end{tabular}

$*(p<0.05)$

\section{Effects of the calcitonin in the bone repair of alveolar socket}

It was verified a large variability in the process of bone repair of the studied groups. At 15 days postoperative, no blood clot was noted in the control groups. The diabetic groups presented blood clot only in the periods of 15 and 30 days. However, in the DCa group a significant difference with D groups $(p<0.001)$ was detected. This initial aspect could suggest that the calcitonin accelerated bone repairing. Histomorphometric analysis allowed quantification of progressive bone neoformation in parallel to decrease in the volume fraction of connective tissue up two months after dental extraction. It also showed a significantly smaller volume fraction of bone trabeculae in the D-group compared with control situation. For DCa-group the development of bone formation improved progressively. The healing process in DCa-group closely resembled data regarding control rats, however this hormone was still not sufficient to revert the delay on dynamic bone repair, observed in diabetes condition.

\section{Histological Analysis}

In order to facilitate the description of the results, the alveolus was divided into three thirds: cervical, middle and apical considered from the alveolar bone crest, in direction to the bottom of the alveolus.

\section{5 days}

\section{Control Group}

The cervical third was completely filled with osteogenic connective tissue and by a discrete quantity of immature and irregular bone trabeculae. This tissue was well cellularized and vascularized, and exhibited delicate collagen fibers with irregular arrangement. In the middle third, we observed that the alveolus was filled with immature osseous tissue and a moderate quantity of osteogenic connective tissue while the apical third was completely filled with thick immature and mature bone trabeculae (Figure 1).

\section{Diabetic Group}

The cervical third was filled with well-cellularized loose connective tissue that exhibited moderate and diffuse mononuclear inflammatory cell infiltrate. Scarce immature and delicate bone trabeculae nearby the cortical wall, as well as areas of blood clot and interstitial hemorrhage were also evident. At this region, the presence of a discrete mononuclear inflammatory cell infiltrate was verified. In some areas, foci of abscess areas underlying the lining epithelium were noticed. In the middle third, the presence of loose connective tissue, irregular bone trabeculae and osteoid tissue and unorganized blood clot was noticed. The apical third was filled with blood clot, loose connective tissue, and immature bone trabeculae. These trabeculae were located in the extremities of the alveolus and the clot in the central portion (Figure 2).

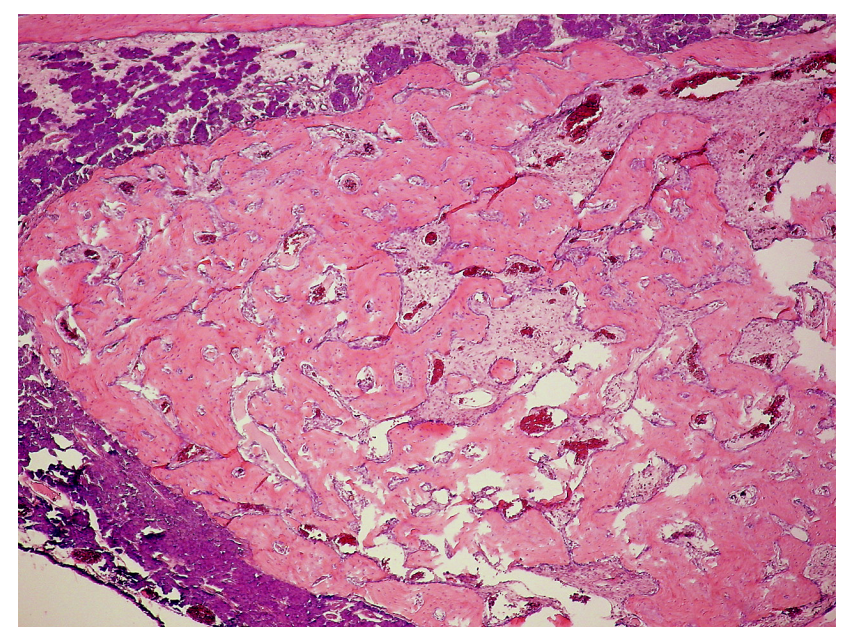

Figure 1 - Control group with 15 days. 


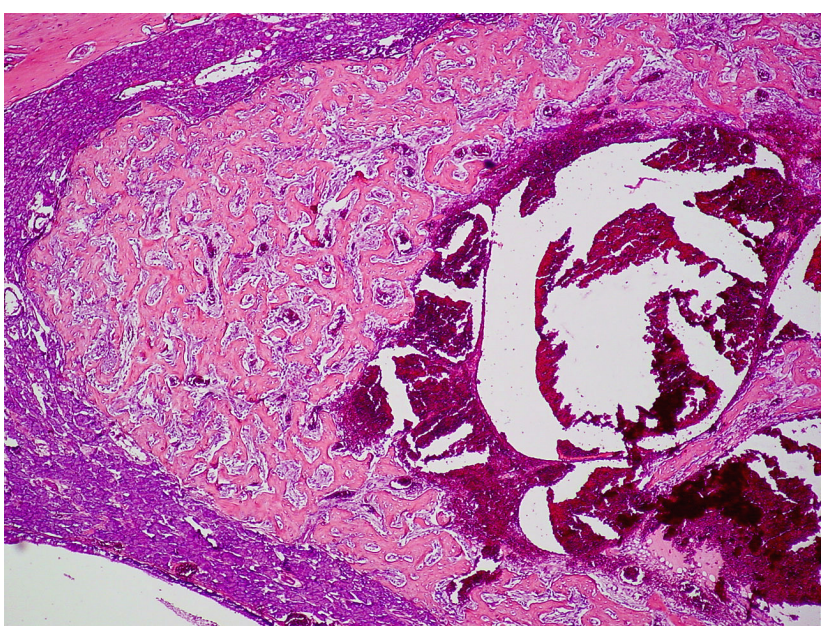

Figure 2 - Diabetic group with 15 days.

\section{Diabetic Group treated with calcitonin}

The cervical third was filled with loose connective tissue and with some immature bone trabeculae. This tissue exhibited discrete and diffused mononuclear inflammatory cell infiltrate. In the middle third, the presence of a great quantity of immature bone trabeculae and osteogenic connective tissue was noticed. The apical third was filled with loose connective tissue, organizing blood clot, and immature bone trabeculae. The absence of inflammatory infiltrate was also evident (Figure 3).

\section{0 days}

\section{Control Group}

The cervical third was filled with loose connective tissue and with immature bone trabeculae. The presence of numerous engorged blood vessels associated to large areas of interstitial hemorrhage was observed. The bone trabeculae were present in greater quantity nearby the cortical bone than in the central region of the alveolus. The middle and apical thirds were filled with immature bone trabeculae and osteogenic connective tissue. These trabeculae were well cellularized and exhibited irregular arrangement. The presence of numerous engorged blood cells and focal areas of interstitial hemorrhage in the central portion were noticed.

\section{Diabetic Group (D)}

The cervical third was filled with loose connective tissue and with some immature bone trabeculae. It was observed the presence of moderate mononuclear inflammatory cell infiltrate and engorged blood vessels. The trabeculae were located especially nearby the cortical walls. The middle third was filled with immature bone trabeculae and with loose connective tissue. The apical third was filled with immature bone trabeculae and was permeated with osteogenic connective tissue.

\section{Diabetic group treated with calcitonin (Dca)}

The cervical third was filled with loose connective tissue and with immature bone trabeculae. This tissue exhibited moderate mononuclear inflammatory cell infiltrate and few blood vessels. The middle and apical thirds were filled with immature bone trabeculae and with osteogenic connective tissue. The bone trabeculae were irregularly distributed along all the thirds extension.

\section{5 days}

\section{Control group (C)}

The three thirds were completely filled by osseous tissue. This tissue was characterized by bone trabeculae both thick and delicate, localized nearby the cortical bone and the central portion respectively. We observed the presence of osteogenic connective tissue permeated by bone trabeculae. The cortical walls were whole and the alveolus surface was completely covered with keratinized stratified pavement epithelium, without any sign of infection (Figure 4).

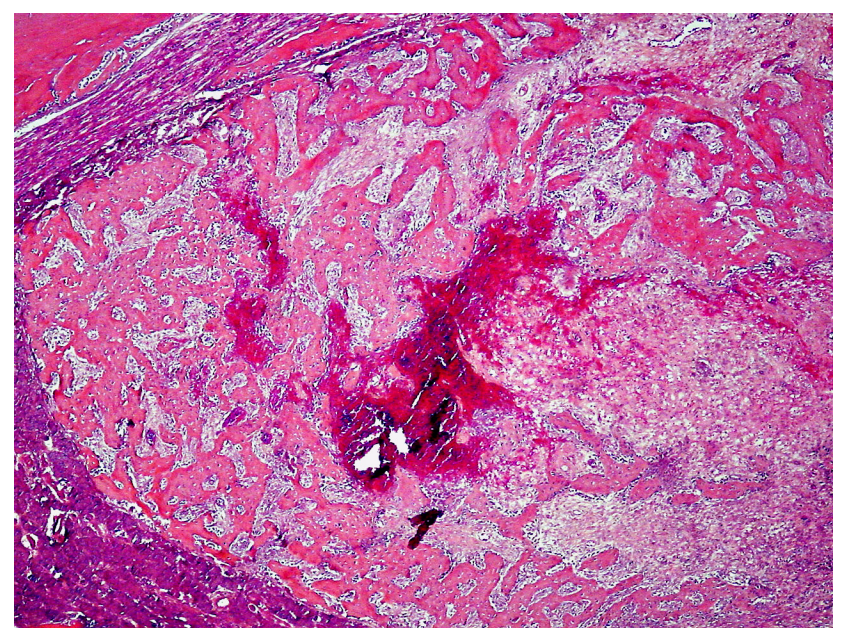

Figure 3 - Group diabetic+calcitonin with 15 days. 


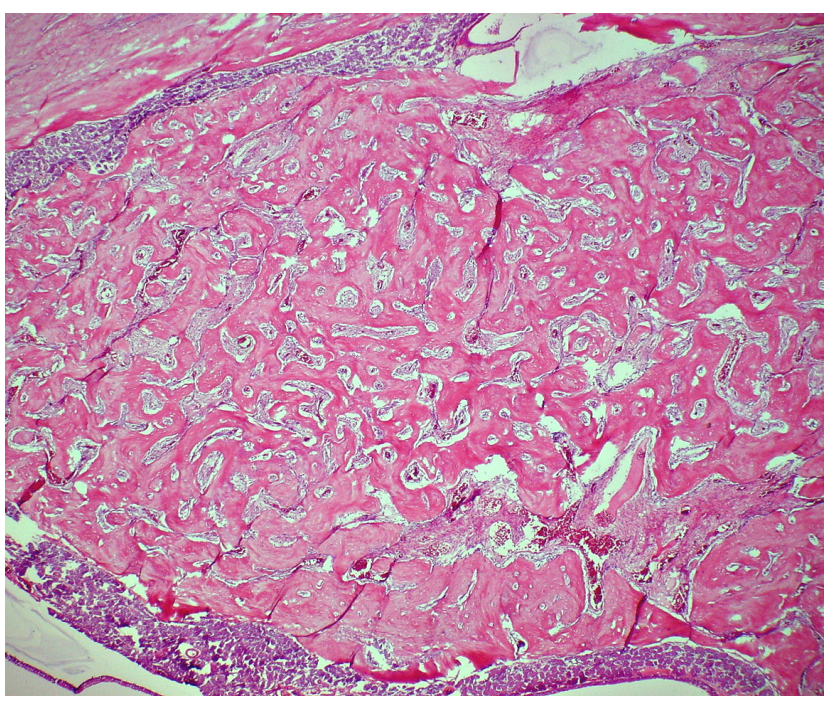

Figure 4 - Control group with 45 days.

\section{Diabetic group (D)}

The three thirds were filled by osseous tissue and in some areas the presence of osteogenic connective tissue was noticed. This tissue, in the cervical region, exhibited discrete mononuclear inflammatory cell infiltrate and engorged blood vessels. The surface of the alveolus was partially covered by keratinized pavement epithelium (Figure 5).

\section{Diabetic group treated with calcitonin (Dca)}

The three thirds were filled with immature bone trabeculae permeated by loose and osteogenic connective tissue. This tissue was more abundant in the middle and cervical thirds than in the apical third (Figure 6).

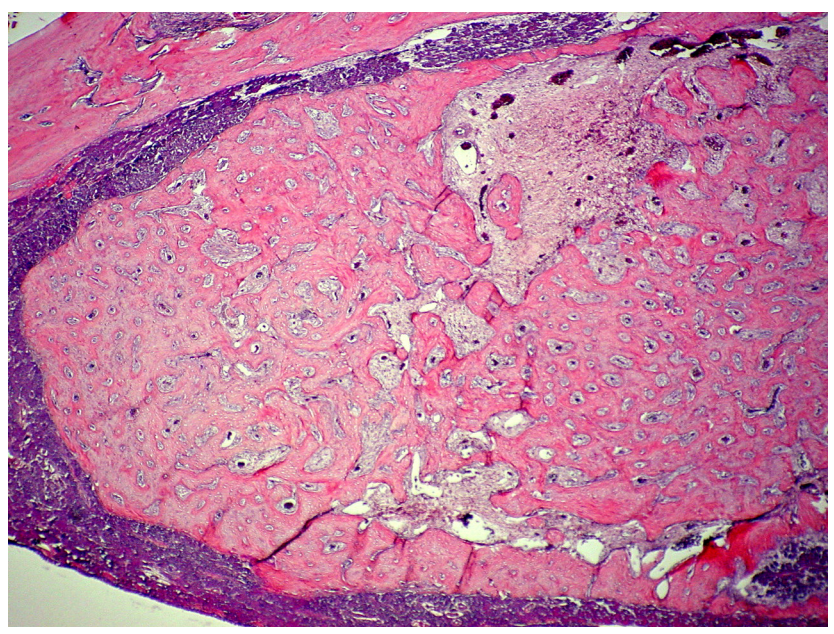

Figure 5 - Diabetic group with 45 days.

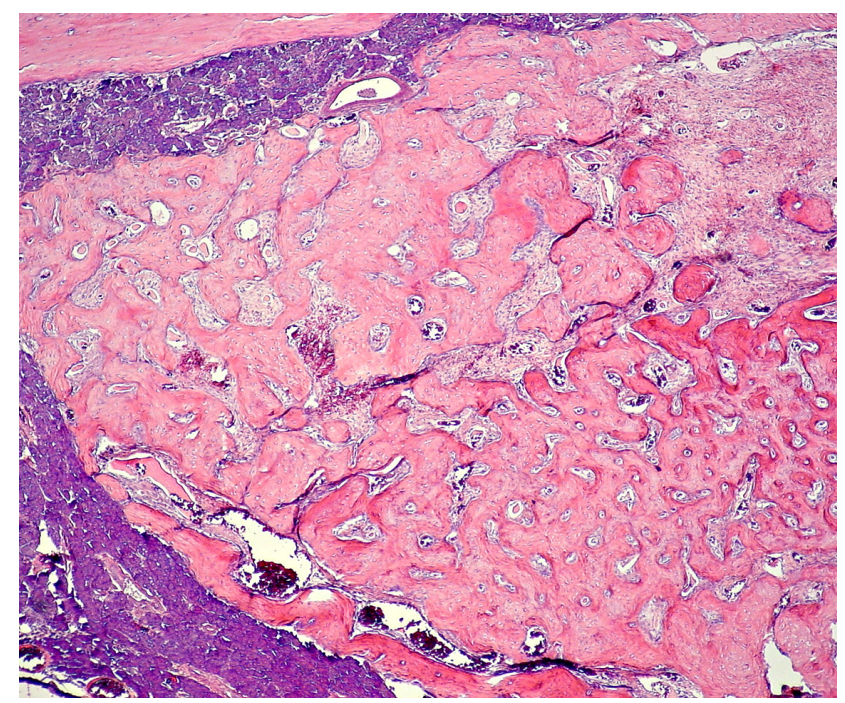

Figure 6 - Group diabetic+calcitonin with 45 days.

\section{Histomorphometric analysis}

The histomorphometric results showed that, during the 15-30-45-days periods, the density of bone tissue in the diabetic group treated with calcitonin (Dca) was lower than the control group (C) and greater than the diabetic group (D). We believe that calcitonin partially reverses the deleterious effects of diabetes in relation to the dynamics of the alveolar bone repairing process. This hormone acts on specific receptors of the osteoclasts and prevents osteoclast recruitment and differentiation of mesenchymal cells to osteoclasts, and may promote inhibition of bone resorption [19-21]. Microscopically, it was observed that the dynamics of bone healing in the diabetic group was delayed. This fact could be explained due to reduction of insulin release, which seems to decrease collagen production; bone turnover is depressed caused to the inactivation of osteoblasts followed by impaired osteoclast activity; decreased protein synthesis and phosphatase activities in osteoblasts; changes in extracellular matrix components and bone metabolism promoted by advanced glycation

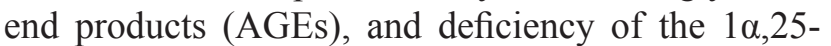
dihydroxy vitamin D3 [4,12,22-24].

\section{Discussion}

We have shown that chronic treatment of salmoncalcitonin improved bone repair after dental extraction. Many patients with diabetes mellitus have shown a moderate reduction in bone mass as result of the altered metabolism of bone and mineral [25-27]. There are some evidences proposing mechanisms for this 
disturbance Hyperglycemia promote the generation of AGEs products. The accumulation of AGEs on log-lived proteins has been shown accelerated in advanced aging and diabetes mellitus. Therefore, AGEs are postulated to be linked to development of some complications in aging and diabetes. Several studies have shown that AGE-modified proteins perturbed cellular functions, including cytocine and growth factor release, alter synthesis of extracellular matrix components. It has been demonstrated AGEs accumulated on collagen derived from cortical bones of diabetic or aged rats [7,28,29]. Recent studies described that AGEs enhanced the production of bone resorption factor IL-6 in normal human bone-derived cells $[8,22,30]$. The cellular interactions of AGEs have been shown to be mediated by the receptor for AGE (RAGE), a member of the immunoglobulin superfamily.

Otherwise, hyperglycemia and glycosuria increase the loss of $\mathrm{Ca}$ in urine by decreasing the tubular reabsorption of $\mathrm{Ca}$ resulting in secondary hyperparathyroidism and loss of bone mineral [25,3132]. In humans, hypercalciuria and osteopenia often follow type I diabetes mellitus [11-12,33].

Studies related that high glucose significantly decreases the number of $1,25(\mathrm{OH}) 2 \mathrm{D} 3$ receptors in MG-63 cells, impairs cell function and contributes to defect in bone formation observed in the patients with diabetic osteopenia [11,25,34].

In age and diabetes-related osteoporosis, decreased bone formation as well as decrease bone resorption have been observed. Bone is a complex tissue in witch resorption and formation continues through life. This process is called bone remodeling.

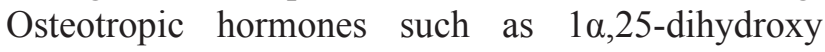
vitamin D3[1 $225(\mathrm{OH}) 2 \mathrm{D} 3]$, PTH and Calcitonin preferentially modulate the process of bone resorption to maintain bone remodeling.

Salmon calcitonin $(\mathrm{sCT})$ is a therapeutic agent other than estrogen currently approved by the Food and Drug Administration for the treatment of established osteoporosis. The National Osteoporosis Foundation recommends the used of calcitonin or biphosphonates with therapy by treatment of osteopenia [35]. In fact, calcitonin is widely used as a valuable agent in the management of Paget's disease, in a prevention of bone loss in early post-menopausal women besides osteoporosis [13,35-36].

Diabetes specific complications have been related to long-term increases in blood glucose concentrations. Glucose metabolites formed alter many cell processes and the formation of tissues. One class of irreversible molecules formed has been termed Advanced Glycation End-products (AGEs). AGEs accumulate over a period of years on long-lived extracellular and/or intracellular macromolecules such as proteins and lipids. AGEs cause qualitative and quantitative changes in extra cellular matrix components such as collagen, proteoglycans, laminin, and vitronectin. These changes in the extra cellular matrix cause specific alterations in bone formation and remodeling [5,7-8].

One of the many actions of salmon calcitonin observed early in its development for therapeutic use was the elevation of plasma glucose, a diabetogenic action. This action has attributed to inhibition of insulin secretion [16,37]. However other studies have shown lack of diabetogenic effects of long term treatment with $\mathrm{SCT}$ [16-17,38-39] and suggested that high doses of calcitonin can be given to patients with impaired glucose tolerance or to diabetics, without any risk of deteriorating their metabolic control during the early weeks of treatment [40-41].

\section{Conclusion}

In conclusion calcitonin-treated animals altered of wound healing after dental extraction, attenuating the impairment of the dynamic bone repair commonly observed in the diabetic status.

\section{AcKnOWLedgments}

This research work was supported by grant from Fundação de Amparo a Pesquisa do Estado de São Paulo (FAPESP) - no 00/10725-2. The authors wish to thank to Domingos Gonçalves Pontes for helping in the surgical produces and administration of the drugs in the experimental animals. 


\section{Resumo}

A fim de fazer uma avaliação histomorfométrica da cicatrização em feridas crônicas do alvéolo dental na presença de calcitonina de salmão (16UI/Kg) em 60 ratos albinos diabéticos. Estes animais foram divididos em três grupos: controle (C), diabético (D) e diabéticos tratados com calcitonina (Dca). Os grupos D e Dca receberam uma injeção única 45mg/ $\mathrm{Kg}$ intraperitonial de estreptozotocina-STZ. Depois de duas semanas, todos os animais foram submetidos a exodontia do dente incisivo superior direito e cinco animais de cada grupo foram sacrificados aos 15, 30 e 45 dias pós-operatórios. As peças foram fixadas, descalcificadas e embebidas em parafina. Dessa forma os blocos obtidos foram cortados com 6 micrômetros de espessura e foram corados com hematoxilina e eosina para estudo morfológico. De acordo com os resultados obtidos, verificou-se que os animais tratados com calcitonina tiveram a cicatrização da ferida após a exodontia dentária alterada, o que atenuou o comprometimento da reparação óssea, geralmente observada no estado diabético.

\section{Palavras-chave}

Reparação óssea; diabetes mellitus; calcitonina de salmão; alvéolo dentário; estreptozotocina.

\section{RefERENCES}

1. Vernillo AT. Diabetes mellitus: relevance to dental tretment. Oral Surg Oral Med Oral Pathol. 2001;91(3):263-70.

2. Arsa G, Lima L, Almeida SS, Moreira SR, Campbell CSG RT et al. Diabetes Mellitus tipo 2: Aspectos fisiológicos, genéticos e formas de exercício físico para seu controle Rev Bras Cineantropom Desempenho Hum. 2009;11(1):103-11.

3. Schneider LE, Wilson HD, Scheld HP. Intestinal calcium binding protein in the diabetic rat; Nature.1973;245(5424):327-8.

4. Takeshita N, Yoshino T, Mutoh S, Yamaguchi I. Possible involvement of vitamin D3-deficiency and relatively enhanced bone resorption in the development of bone loss in streptozotocin-induced diabetic rats. Life Sci.1994;55(4):291-9.

5. Fiorellini JP, Nevins ML, Norking A, Weber HP, Karimbux NY. The effect of insulin therapy on osseointegration in a diabetic rat model. Clin Oral Impl Res. 1999;10(5):362-8.

6. Wang F, Song Y, Li D, Li C, Wang Y, Zhang N et al. Type 2 diabetes mellitus impairs bone healing of dental implants in GK rats. Diabetes Res Clin Pract. 2010; 88(1): e7- e9.

7. Goldin A, Beckman JA, Schmidt AM, Creager MA. Advanced glycation end products: sparking the development of diabetic vascular injury. Circulation. 2006; 114(6):597605.

8. Goh SY, Cooper ME. The role of advanced glycation end products in progression and complications of diabetes. J Clin Endocrinol Metab. 2008;93(4): 1143-52.

9. Sousa MGM, Costa ALL, Roncalli AG. Clinical study of the oral manifestations and related factors in type 2 diabetics patients. Braz J Otorhinolaryngol. 2011; 77(2):145-52.

10. Capelle MAH, Gurny R, Arvinte T. A high throughput protein formulation platform: case study of salmon calcitonin. Pharm Res. 2009;26(1):118-28.

11. Musumeci G, Loreto C, Clementi G, Fiore CE, Martinez G. An in vivo experimental study on osteopenia in diabetic rats. Acta Histochem. 2011;113:619-25.

12. Ward DT, Yau SK, Mee AP, Mawer EB, Miller CA, Garland HO, Riccardi D.(2001). Functional, molecular, and biochemical characterization of streptozotocin-induced diabetes. J Am Soc Nephrol. 2001;12: 779 -90.

13. Wronski, TJ, Yen CF, Burton KW, Mehta RC, Newman PS,
Soltis EE et al. Skeletal effects of calcitonin in ovariectomized rats. Endocrinology. 1991;129(4): 2246-50.

14. Gomes MF, Dos Anjos MJ, Nogueira T de O, Catanzaro Guimarães SA. Autogenous demineralized dentin matrix for tissue engineering applications: radiographic and histomorphometric studies. Int $\mathrm{J}$ Oral Maxillofac Implants.2002; 17(4):488-97.

15. Giugliano D. Calcitonin and the human endocrine pancreas. Biomed Pharmacother. 1984;38(5):273-7.

16. Young AA, Wang M-W, Gedulin B, Rink TJ, Pittner R, Beaumont K. Diabetogenic effects of salmon calcitonin are attributable to amylin-like activity. Metabolism. 1995;44(12):1581-89.

17. Bulbul M, Esenyel CZ, Esenyel M, Ayanoglu S, Bilgic B, Gulmez T. Effects of calcitonin on the biomechanics, histopathology, and radiography of callus formation in rats.J Orthop Sci. 2008;13(2):136-44.

18. Feigh $\mathrm{M}$, Henriksen $\mathrm{K}$, Andreassen $\mathrm{KV}$, Hansen $\mathrm{C}$, Henriksen JE, Beck- Nielsen H, et al. A novel oral form of salmon calcitonin improves glucose homeostasis and reduces body weight in diet-induced obese rats. Diabetes Obes Metab; 2011:13(10):911-920.

19. Hedlud T, Hulth A, Johnell O. Early effects of parathormone and calcitonin on the number of osteoclasts and on serumcalcium in rats. Acta Orthop Scand. 1993;54(6):802-4.

20. Farley JR, Hall SL, Herring S, Tarbaux N M. Two biochemical indices of mouse bone formation are increased, in vivo, in response to calcitonin. Calcif Tissue Int. 1992;50(1):67-73.

21. Lieberman JR, Daluiski A, Einhorn TA. The role of growth factors in the repair of bone biology and clinical applications. J Bone Joint Surg. 2002;84(6):1032-44.

22. Takagi M, Kasayama S, Yamamoto $T$, Motomura $T$, Hashimoto K, Yamamoto H. Advanced glycation endproducts stimulate interleukin-6 production by human bone-derived cells. J Bone Miner Res. 1997;12(3):439-46.

23. Giglio MJ, Giannunzio G, Olmedo D, Guglielmotti MB. Histomorphometric study of bone healing around laminar in experimental diabetes. Implant Dent. 2000;9(2):143-9.

24. Mota NL, Castro Júnior AF, Castro BK, Silveir Neto LL, Aarestrup BJV. Embriologia e histofisiologia do tecido ósseo: revisão de literatura e bases histofisiológicas das principais doenças ósseas metabólicas. Bol Centro Biol Reprod. 2008;27(1/2):27-32.

25. Inaba $M$, Terada $M$, Koyama $H$, Yoshida $O$, Ishimura 
E, Kawagishi T. Influence of high glucose on 1,25-dihidroxyvitamin D3- induced effect on human osteoblast-like MG-63 cells. J Bone Miner Res. 1995;10(7):1050-56.

26. Lu H, Kraut D, Gerstenfeld LC, Graves DT. Diabetes interferes with the bone formation by affecting the expression of transcription factors that regulate osteoblast differentiation. Endocrinology. 2003;144(1):346-52.

27. Lappin DF, Eapen B, Robertson D, Young J, Hodge PJ. Markers of bone destructionand formation and periodontitis in type 1 diabetes mellitus. J Clin Periodontol. 2009;36:63441.

28. Tomaseck JJ, Meyers SW, Basinger JB, Grenn DT, Shew RL. Diabetic and age-related enhancement of collagenlinked fluorescence in the cortical bones of rats. Life Sci. 1994;55(11):855-61.

29. Singh R, Barden A, Mori T, Beilin L. Advanced glycation end-products: a review. Diabetology. 2001;44(2):129-46.

30. Thomas MV, Puleo DA. Infection, inflammation, and bone regeneration: a paradoxical relationship. J Dent Res. 2011;90(9):1052-61.

31. Nathan D, Buse JB, Davidson MB, Ferrannini E, Holman RR, Sherwin $\mathrm{R}$ et al. Medical management of hyperglycemia in type 2 diabetes: a consensus algorithm for the initiation and adjustment of therapy. Diabetes Care. 2009;32(1):193-203.

32. German JP, Thaler JP, Wisse BE, Oh-I S, Sarruf DA, Matsen $\mathrm{ME}$, Fischer JD, et al. Leptin activates a novel cns mechanism for insulin-independent normalization of severe diabetic hyperglycemia. Endocrinology. 2011;152(2):394-404.

33. Pittas AG, Lau J, Hu FB, Dawson-Hughes B. Review: the role of vitamin $\mathrm{d}$ and calcium in type 2 diabetes. a systematic review and meta-analysis. J Clin End Metabol. 2007;92(6):2017-29.

34. Duarte VMG, Ramos AMO, Rezende LA, Macedo UBO, Brandão-Neto J, Almeida MG, et al. Osteopenia: a bone disorder associated with diabetes mellitus. J Bone Miner Metab. 2005;23:58-68.

35. Chau DL, Eldeman SV. Osteoporosis and diabetes. Clin Diabet. 2002;20 (3):153-7.

36. Li B, Chau JFL, Wang X, Leong WF. Bisphosphonates, specific inhibitors of osteoclast function and a class of drugs for osteoporosis therapy. J Cell Biochem. 2011;112(5):1229-42.

37. Sun JY, Jing MY, Wang JF, Weng XY. The approach to the mechanism of calcitonin gene-related peptide-inducing inhibition of food intake. J Anim Physiol Anim Nutr. 2010;94(5):552-60.

38. Giustina G, Cerudelli B, Cimino A, Rigosa C, Rotonti A, Radaeli E. Synthetic salmon calcitonin is not diabetogenic in patients with normal or impaired glucose metabolism. J Endocrinol Invest. 1985;8(1):19-23.

39. Arisawa EAL, Brandão AAH, Almeida JD, Rocha RF: Calcitonin in bone-guided regeneration of mandibles in ovariectomized rats: densitometric, histologic and histomorphometric analysis. Int J Oral Maxillofac Surg. 2008;37(1): 47-53.

40. Passariello N, Giugliano D, Sgamabato S, Torella R, D'Onofrio F. Calcitonin, a diabetogenic hormone? J Clin Endocrinol Metab. 1981;53(2):318-23.

41. Karsdal MA, Byrjalsen I, Henriksen K, Riis BJ, Christiansen C. Investigations of inter- and intraindividual relationships between exposure to oral salmon calcitonin and a surrogate marker of pharmacodynamic efficacy. Eur J Clin Pharmacol.2010;66(1):29-37.
Received: 01/06/2012

Accepted:02/10/2012

Corresponding author: José Benedito de Oliveira Amorim Faculdade de Odontologia de São José dos Campos - UNESP Departamento de Biociências e Diagnóstico Oral Av. Eng. Francisco José Longo, 777 / Cep: 12.245-000 São José dos Campos / São Paulo / Brasil amorim@fosjc.unesp.br 